\title{
Histology and Histopathology of the Lutjanus johni (Bloch, 1792) and Lutjanus russelli (Bleeker, 1849) from Visakhapatnam Coast, India
}

\author{
Sowjanya Pilla ${ }^{* 1}$, Rajesh Konathala ${ }^{2}$, Ratnakala $\mathrm{M}^{1}$, Sree Ramulu $\mathrm{K}^{1}$ \\ 1Department of Zoology, Andhra University, Visakhapatnam-530 003. A.P. India \\ 2 Department of Pharmacology, Andhra University, Visakhapatnam-530 003. A.P. India \\ *Author for Correspondence
}

\begin{abstract}
Histopathologic changes caused by digeneans and nematodes in the liver of Lutjanus johni (Bloch, 1792) and Lutjanus russelli (Bleeker, 1849) were studied. For this purpose histological sections were prepared and stained by routine procedures with haematoxylin and eosin and mounted permanently in Canada balsam. Photographs of selected portions were prepared in support of the damage caused by the parasites. The histopathologic changes caused by the Paracryptogonimus hirastrictus Manter, 1963 (Digenea: Cryptogonimidae) and Raphidascaris lutiani Raillietet Henry, 1915 (Nematoda: Heterocheilidae) include severe destruction and necrosis liver tissue. Destruction of epithelial cells, inflammation and an increase in thickness of sub-mucosa, atrophy and aggregation of inflammatory cells between hepatocytes.

Key Words: Atrophy, Canada balsam, Digenea, Eosin, Haematoxylin, Hepatocytes, Necrosis, Nematoda, Paracryptogonimus hirastrictus and Raphidascaris lutiani.
\end{abstract}

\section{Introduction:}

Lutjanus are commonly known as Snappers and belong to the family Lutjanidae. These are rocky fish and abundantly occur throughout the Indian coast. These fishes are commercially known for their delicacy as food fish and have good quality of proteins and other nutrients. They harbour a wide variety of parasitic fauna.

The aim of the present study is to evaluate histology and histopathological alterations caused by the metazoan parasitic fauna in gill and liver of the Lutjanus johni and L.russelli.

Fish liver is a very interesting model for the study of interactions between environmental factors and hepatic structures and functions (Brusle and Anadon 1996; Velvoka and Kostoski, 2005). Thus research on fish liver is important, especially in the field of problems induced by aquaculture conditions, aquatic pollution and diseases (Gochfeld, 2003; Bertolucci et al., 2008).

Many workers have made contributions to the histopathological diagnosis of liver. Rocha et al., (1997) described the liver of brown trout, Salmo trutta (Teleostei, Salmonidae). Rodrigues and Fanta, (1998) made investigation on liver hisopathology of the fish Brachydanio rerio). Moniruzzan (2000) made investigation on disease of some small indigenous fresh water fishes. Mohamed (2001) studied on the histological structures of the liver and intestine of Oreochromis niloticus and Tilapia zilli. Camargo and Martinez (2007) studied on histopathology of gills, kidney and liver of Neotropical fish caged in an urban stream. Marina et al., (2007) also defined histopathology of gills, kidney and liver of Neotropical fish. Fatma and Mohamed (2009) studied histopathological studies on Tilapia zillii and Solea vulgaris.

Many parasitologists studied histopathology caused by helminth parasites which cause damage to its habitat with the strong armed holdfast organs. The distribution of parasites within the fish liver is variable and they may damage the liver at the point of their attachment. Pathological consequences of parasitic diseases of fishes are well documented and serve as an evidence to support the view that parasites are one of the main causes of mortality in fish population (Paperna and Vanas, 1983 and Orecka-Grabda, 1991).

Pathological studies have been made earlier by several authors on the trematodes in fish which include that of Hoswell (1973), Gupta and Sharma (1974), Srivastava and Mukherjee (1976), Bose and Sinha (1979), Barbarna (1980), Muzzal (1980), Lester (1980), Chung Yui-tan (1981), Christina (1982), Bhargavi and Krishna (1983), Pike and Burt (1983), Sinhaet al., (1988), Agarwal and Agarwal (1989), Zaman (1990), Watson etal., (1992), Coleman (1993), Sharadamma (1994), Ismail (1996), Nelson et al., (1997), Dezfuliet al., (1995, 2002, 2003), Laxma Reddy and Benarjee (2006) and Rio-Zaragoza et al., (2010).

\section{Material and methods:}

Specimens of the Lutjanus species were collected from the Visakhapatnam coast for pathological observations. After the dissection of the fish, the whole gill was removed from fish and examined for copepod parasites. Pieces of gill tissue with attached parasites were fixed in susa, dehydrated with alcohol and embedded 
in paraffin. Afterwards, these blocks were serially sectioned at about $5 \mu \mathrm{m}$ and stained with haematoxylin-eosin. The stained sections were observed under light microscope and micro photographs were taken for pathological observations.

\section{Results:}

The pathological changes due to the infection of different parasites were observed in the present study. Focus is made on 2 parasites i.e.,Paracryptogonimus hirastrictus and Raphidascaris lutiani that have destructive affect on the Lutjanus johniand L.russelli.

Histopathological changes were observed in the liver of Lutjanus fishes.

1. Liver of Lutjanus johnii is infected with Raphidascaris lutiani (nematode)

2. Liver of Lutjanus russelli is infected with Paracryptogonimus hirastrictus (digenea)

\section{Histology: (Fig. 1)}

Histologically, the liver of Lutjanus species is composed of a parenchyma covered by a typical serosa over lining a thin connective tissue capsule. Interlobular connective tissue is scant and difficult to see and the lobulation is not seen in the liver clearly. The parenchyma consists of branching sheets of tissue, each one or two cells thick, radiating out from central veins. The sheets are separated by sinusoids are covered by endothelial cells with flatten nucleus.

Hepatocytes vary in shape from round to oval. Each hepatocyte contains a large, round, centrally situated nucleus with a prominent dark nucleus. Hepatocytes had many eosinophilic vacuoles, among them sinusoids were present. Some of the hepatocytes surface lines connect the sinusoidal channels (sinusoidal surface), while other surfaces are in contact with adjacent hepatocyte (intracellular surfaces). Some of the adjacent hepatocyte surfaces have bile canaliculi running between them. The blood capillaries in the liver mass which are often termed as the hepatic sinusoids are irregular and thin walled. The lumen of the sinusoids contains erythrocytes and macrophages. Large cells resting on the luminal surface of the sinusoid endothelium are present. These cells are known as kupffer cells. Sinusoids are covered by typical endothelial cells with flatten nucleus. Kupffer cells were found among the sinusoidal endothelium, these cells were small and few in number. There were no epithelial cells in bile canaliculi except for hepatic cell walls that were connected to interlobular bile ducts with sample cuboidal cells.

The cytoplasm is vacuolated and highly granular with alternating light and densely staining region variably in the cell. The cytoplasm is usually densely stained around the nucleus and slightly stained towards the periphery of the cell wall.

\section{Pancreas}

The pancreatic tissue is more variable in location, even within a single species, than the other abdominal viscera. In this Lutjanus species, it surrounds the portal vessels entering the liver to form a hepatopancreas. The pancreas is also scattered in the liver. Numerous pancreatic tissues are observed in liver sections.

The pancreas consists of two types of tissues: exocrine and endocrine.

\section{Exocrine Pancreas}

Thin septa of connective tissue separated exocrine pancreatic cells from the hepatocytes. The exocrine pancreas was arranged around a branch of the portal vein, separated by a basal membrane and reticular fibers.

\section{Endocrine Pancreas}

Endocrine part of pancreas was observed among exocrine acinar cells in the form of few cell masses in various sizes. Langerhans Islets were surrounded by a delicate connective tissue. The Islets of Langerhans is large and of all sizes was found within the evenly distributed exocrine tissue. The Islets of Langerhans consists of a number of lightly capsulated, spherical masses or clusters of plate staining glandular cells. The size of islet cells may vary with season. And in some species, there is one major islet, known as the Brockmann body.

\section{Liver-Histopathology: (Fig. 2\&3)}

In the present study, liver is parasitized by Paracryptogonimus hirastrictus (digene) and Raphidascaris lutiani (Nematode). They protrude the liver and shows tissue damage. conditions.

The microscopic study of tissues affected by the helminth parasites revealed different pathological

The most common lesions in the liver were vacuolar degeneration in the hepatocytes, focal areas of necrosis and aggregations of inflammatory cells between the hepatocytes. The vacuolization of hepatocytes might indicate an imbalance between the rate of synthesis of substances in the parenchymal cells and the rate of 
release into the circulation system. Dilation and thrombosis formaton in central veins, dilation and congestion in blood sinusoids and intravascular hemolysis in hepatic blood vessels and hepatoportal blood vessels were observed. Moreover, focal areas of coagulative necrosis and fibrosis were seen.

The organ most associated with the detoxification and biotransformation process is the liver, due to its function, position and blood supply. It is also one of the organs most affected by helminth parasites, the most common cause of the cellular degeneration observed in the liver. The vascular dilation, intravascular hemolysis and thrombosis formation observed in the blood vessels with subsequent stasis of blood may be also responsible for the cellular degeneration and necrosis in the liver.

The main alteration found in the liver were, irregular-shaped nuclei, nuclear hypertrophy, nuclear vacuolation and the presence of eosinophilic granules in the cytoplasm. Bile stagnation was identified as brownish-yellow granules in the cytoplasm. Bile stagnation was identified as brownish-yellow granules in the cytoplasm. Cytoplasmic and nuclear degeneration was also very common. Melanomacrophages were identified as rounded aggregates of cells containing dark-yellowish granules of various sizes, normally close to the vessels. Examination of infected pancreas revealed degeneration of some glandular cells and presence of few lymphocytes around the acini. No granules were observed.

Extensive tissue damage was observed in liver tissues. Tissues from the liver revealed focal to coalescing necrosis of the interstitial tissue. In the liver, sinusoids were distended and partially filled with granular, eosinophilic material (edema fluid). Many cells with pycnotic nuclei were observed randomly distributed throughout the liver tissue. The tissue damages like degeneration of cytoplasm in hepaocytes, atrophy, formation of vacuoles, rupture in blood vessels and deposition of hepatic cords were the histopathological changes observed in the liver.

L.johni and L.russelli recorded different pathological conditions in the liver. When examined grossly before processing for the histopathologic studies, the surface of the liver obviously appeared abnormal at the site of penetration of parasite. Histological examination revealed that sever distruction has occurred in the whole thickness of liver. The section through the liver of the fish species show deep basophilic staining of blood vessels and calcification of hepatic blood vessels. Numerous haemosiderosis nodules were also observed in the liver of the fish species.

Fig.1: Histology liver tissue (H \&E) a. Hepatocytes b. Exocrine pancreas c. Septa of connective tissue

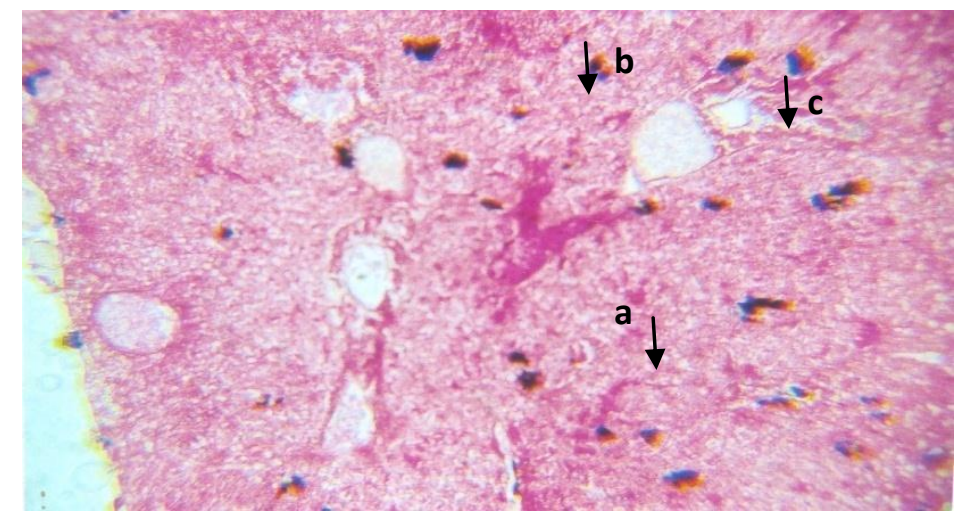

Fig.2: Histopathology of liver tissue a. Section showing nematode parasite b. Hepatocyte c. Exocrine pancreatic tissue 


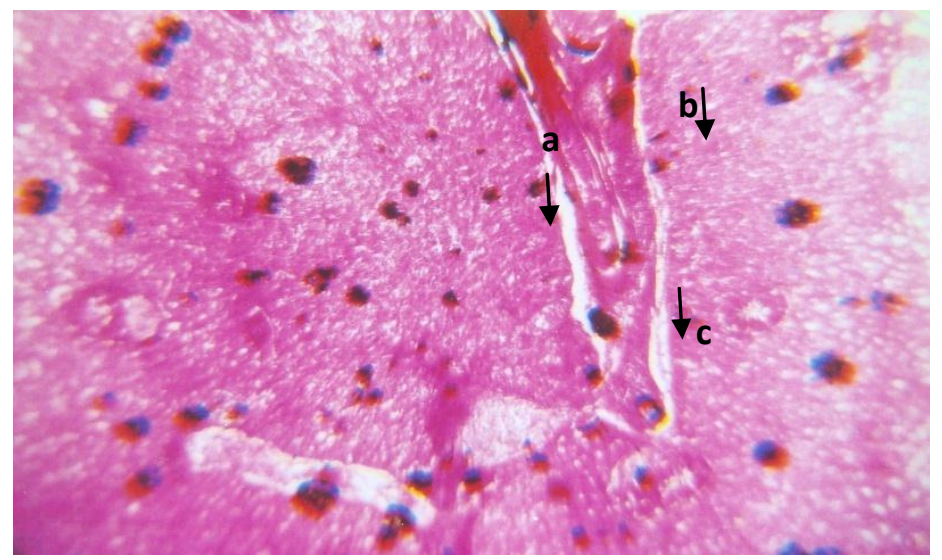

Fig.3: Histopathology of liver tissue a. Section showing digenean parasite b. Hepatocytes

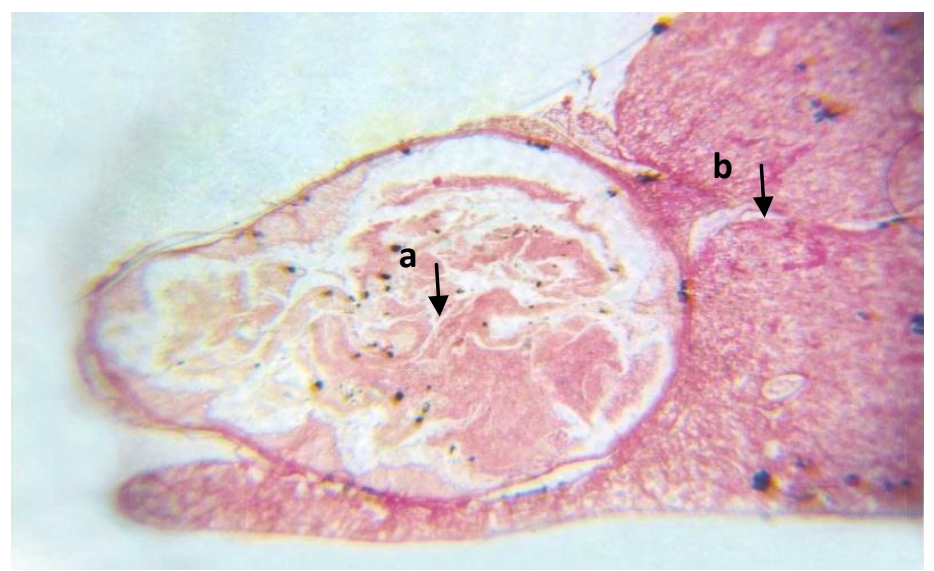

\section{Discussion:}

There are many histopathological reports regarding the perforation of the liver by different genera of Digeneans and Nematode parasites in various hosts. Adult trematodes infecting the liver of fish are considered harmless, even when their numbers are high. In this study, there was no significant pathological change observed in the parasitized organs as a result of trematode infection. Van As and Basson (1984) reported that Clinostomum metacercrial were reported in Parachanna obscura. The clinical affects of infection of these cysts are not obvious. Akinsanya and Hassan (2002a) also reported the presence of Clinostomum marginatum (Yellow grub) metacercaria from Cichlids. Paperna and Lengi (1963), Yekutiel (1985) reported that the large and numerous cysts of Brevimulticaecum levantinus, established in muscles of young Cichlids, induce severe body deformities. Hoglund (1991) established the fact that the cercariae penetrate via the skin and gills. Trout infection with Apatemom gracilis resulted in fibrogranulomatosis of the epicardium and failure in in-vitro pumping performance (Tort et al., 1987, Watson et al., 1992). Rio-Zaragoza et al., (2010) described haematological and gill responses to an experimental infection of dactylogyrid monogeans on the spotted rose Snapper Lutjanus guttatus (Steindachner, 1869).

Infections by nematode parasites in this study did not produce significant pathological conditions. This is an agreement with the work done by Paperna (1964), Khalil (1969), Mashego and Saayman (1980) and Boomker (1982). They reported that infections by Camallanids (Paracamallanus cyathopharynx and Paracamallanus laevionchus) in Clarias species did not produce any pathogenic affects in spite of the firm attachment by their buccal capsule to the stomach mucosa of the fish species. Little harm is also caused by the species of Rhabdochona or Spinitectus, which are common in the intestine of fish of all families (Paperna, 1964; Khalil, 1971).

In the present study, the infected liver showed vacuolar degeneration in the hepatocytes, focal areas of necrosis, thrombosis formation in central veins, dilation and congestion in blood sinusoids and fibrosis. Hepatic hypertrophy, hepatic tumors and other liver diseases are reported to occur at high frequency in the areas with relatively high concentrations of sediment bound polynuclear hydrocarbons. The vacuolization of hepatocytes 
might indicate an imbalance between the rate of synthesis of substances in the parenchymal cells and the rate of their release into the circulation system. The vascular dilation, intravascular haemolysis and thrombosis formation observed in the blood vessels with subsequent stasis of blood may be also responsible for the cellular degeneration and necrosis in the liver, these reports are similar to that of Mohamed (2001); Butchiram et al.,(2009) and Fatma (2009).

Histopathological observations as a whole, affect the health background of the host fish resulting in the depletion of muscle quality, growth, susceptibility for other diseases etc., Though one cannot suggest remedial programs for a marine fish health, it is only interesting and important observation to record which suggests that there may be depletion of muscle quality in infected fish if not mortality. The damage in intestinal wall results in poor absorption, at the same time the parasite is also competing with the host for the digested nutrients there by affecting the health status of the host.

\section{Acknowledgement:}

One of the authors, Sowjanya Pilla is grateful to Prof. K. Sree Ramulu for providing laboratory facilities, Department of Zoology, Andhra University, Visakhapatnam.

\section{References:}

[1]. Altunel FN(1983) Parasitism in Mullets (Mugil species). I. National Congress of The Marine and Freshwater Researches. J of EgeUnivSciFac (B): 364-378

[2]. Deets GB, Kabata Z(1991) Lernanthropus corteziensis sp. (Copepoda, Lernanthropidae), Parasitic On the Gills of A Teleost Fish In Mexican Waters. Systematic Parasitology 18(1): 77-80

[3]. Ho JS, Kim IH(2004) Lernanthropid copepods (Siphonostomatoida) parasitic on fishes of the Gulf of Thailand. Syst Parasitol 58: 17 21

[4]. Ju-shey Ho \&Il-Hoi Kim(2004) Lernanthropid copepods (Siphonostomatoida) parasitic on fishes of the Gulf of Thailand Systematic Parasitology 58: 17-21

[5]. Kabata Z(1979) Parasitic Copepoda of British fishes. The Ray Society London, U.K, 468

[6]. Kinne O(1984) Diseases of Marine Animals. Hamburg Biologische Anstalt Helgoland, Federal Republic of Germany, 521

[7]. Liu WC, Ho JS, Lin CL(2009a) Three species of Lernanthropus de Blainville, 1822 (Copepoda, Lernanthropidae) parasitic on marine fishes of Taiwan J Fish Soc, Taiwan, 36: 29-48

[8]. Liu WC, Ho JS, Lin CL(2009b) Another three species of Lernanthropus de Blainville, 1822 (Copepoda, Lernanthropidae) parasitic on marine fishes of Taiwan, with a key to species of this genus found in Taiwan. J Fish Soc Taiwan, 36: 119-134

[9]. LuqueJL, and Farfan C(1990) Anew species of Lernanthropus Deblainville, 1822. (Copepoda, Lernanthropidae) Parasitic On Menticirrhus ophicephalusJenyns, (Teleostei, Sciaenidae) From the Peruvian Coast. Systematic Parasitology 17(2): 97-101

[10]. ManeraM, Dezfuli BS(2003) Lernanthropus kroyeri infections in farmed sea bass Dicentrachus labrax: pathological features. Dis Aquat Org 57: 177-180

[11]. Olivier PAS, Dippenaar SM, Van Niekerk JP(1997) First report on the morphology of the post antennal process in Lernanthropus(Lernanthropidae: Copepoda) and its possible significance as a taxonomic feature. South African Journal of Zoology $32(2): 43-48$

[12]. Pillai NK(1985) The fauna of India. Copepod parasites of marine fishes. Calcutta: Zoological Society of India. Rosenberg AA. 2008. The price of lice, Nature 451: 23-24

[13]. Timi JT, Etchegoin JA(1996a) A new species of Lernanthropus (Copepoda: Sciaenidae) from Argentinean waters, and new records of Lernanthropus trachuri. Folia parasitological 43: 71-74

[14]. Tokșen E(1999) Metazoon Gill Parasites of Culture Gilthead Sea Bream, Sparus aurata (L.) and Sea bass, Dicentrarchus labrax (L.) in Aegean Sea Coast and Their Treatment. Ege Univ Science Institution Doctora Thesis 153

[15]. Tokşen E, Çağirgan H, Tanrikul TT, Saygi H(2006) The effect of emamectin benzoate in the control of Lernanthropus kroyeri(van Beneden, 1851) (Lernanthropidae) investigation in cultured sea bass, Dicengtrarchus labrax (Linnaeus, 1758). Turk J Vet AnimSci 30: 405-409

[16]. Yamaguti S (1969) Systema parasitic Copepoda and Branchiuran. Inst Sc Publ Newyork-London 